\title{
Optimal management of common acquired melanocytic nevi (moles): current perspectives
}

This article was published in the following Dove Press journal:

Clinical, Cosmetic and Investigational Dermatology

19 March 2014

Number of times this article has been viewed

\section{Kabir Sardana \\ Payal Chakravarty \\ Khushbu Goel \\ Department of Dermatology and STD, Maulana Azad Medical College and Lok Nayak Hospital, New Delhi, Delhi, India}

\begin{abstract}
Although common acquired melanocytic nevi are largely benign, they are probably one of the most common indications for cosmetic surgery encountered by dermatologists. With recent advances, noninvasive tools can largely determine the potential for malignancy, although they cannot supplant histology. Although surgical shave excision with its myriad modifications has been in vogue for decades, the lack of an adequate histological sample, the largely blind nature of the procedure, and the possibility of recurrence are persisting issues. Pigment-specific lasers were initially used in the Q-switched mode, which was based on the thermal relaxation time of the melanocyte (size $7 \mu \mathrm{m} ; 1 \mu \mathrm{sec}$ ), which is not the primary target in melanocytic nevus. The cluster of nevus cells $(100 \mu \mathrm{m})$ probably lends itself to treatment with a millisecond laser rather than a nanosecond laser. Thus, normal mode pigment-specific lasers and pulsed ablative lasers $\left(\mathrm{CO}_{2}\right.$ /erbium [Er]:yttrium aluminum garnet [YAG]) are more suited to treat acquired melanocytic nevi. The complexities of treating this disorder can be overcome by following a structured approach by using lasers that achieve the appropriate depth to treat the three subtypes of nevi: junctional, compound, and dermal. Thus, junctional nevi respond to Q-switched/normal mode pigment lasers, where for the compound and dermal nevi, pulsed ablative laser $\left(\mathrm{CO}_{2} /\right.$ Er:YAG) may be needed. If surgical excision is employed, a wide margin and proper depth must be ensured, which is skill dependent. A lifelong follow-up for recurrence and melanoma is warranted in predisposed individuals, although melanoma is decidedly uncommon in most acquired melanocytic nevi, even though histological markers may be seen on evaluation.
\end{abstract}

Keywords: lasers, surgery, nevus, melanoma

\section{Introduction}

Common acquired melanocytic nevi (CAMN) is a common, largely acquired, condition resulting from benign proliferation of nevus cells. This disorder, also referred to as "signature nevi," has been variably classified depending on the anatomic, architectural, and cellular histological pattern. ${ }^{2}$ Melanocytic nevi form a convenient head to classify the varied manifestations of both congenital and acquired nevi, of which our focus is largely on the common acquired nevi (Figure 1).

The histological spectrum of the melanocytic nevi is bewildering and diverse, with a variety of histologic, anatomic, architectural, and cellular patterns. ${ }^{3}$ There are numerous other terms used, such as "ugly duckling” sign, Spitz's nevi, dysplastic nevi, traumatized nevi, and eponym terms such as Unna, Clark, Reed, Miescher, Zitelli, Mark, Seab, and Ackerman ${ }^{3}$ which complicate the bewildering spectrum of lesions. ${ }^{4}$ Certain vague descriptive terms such as atypical nevus, dysplastic nevus with architectural disorder and moderate to severe cytologic atypia; may represent uncertainty and indecision by 


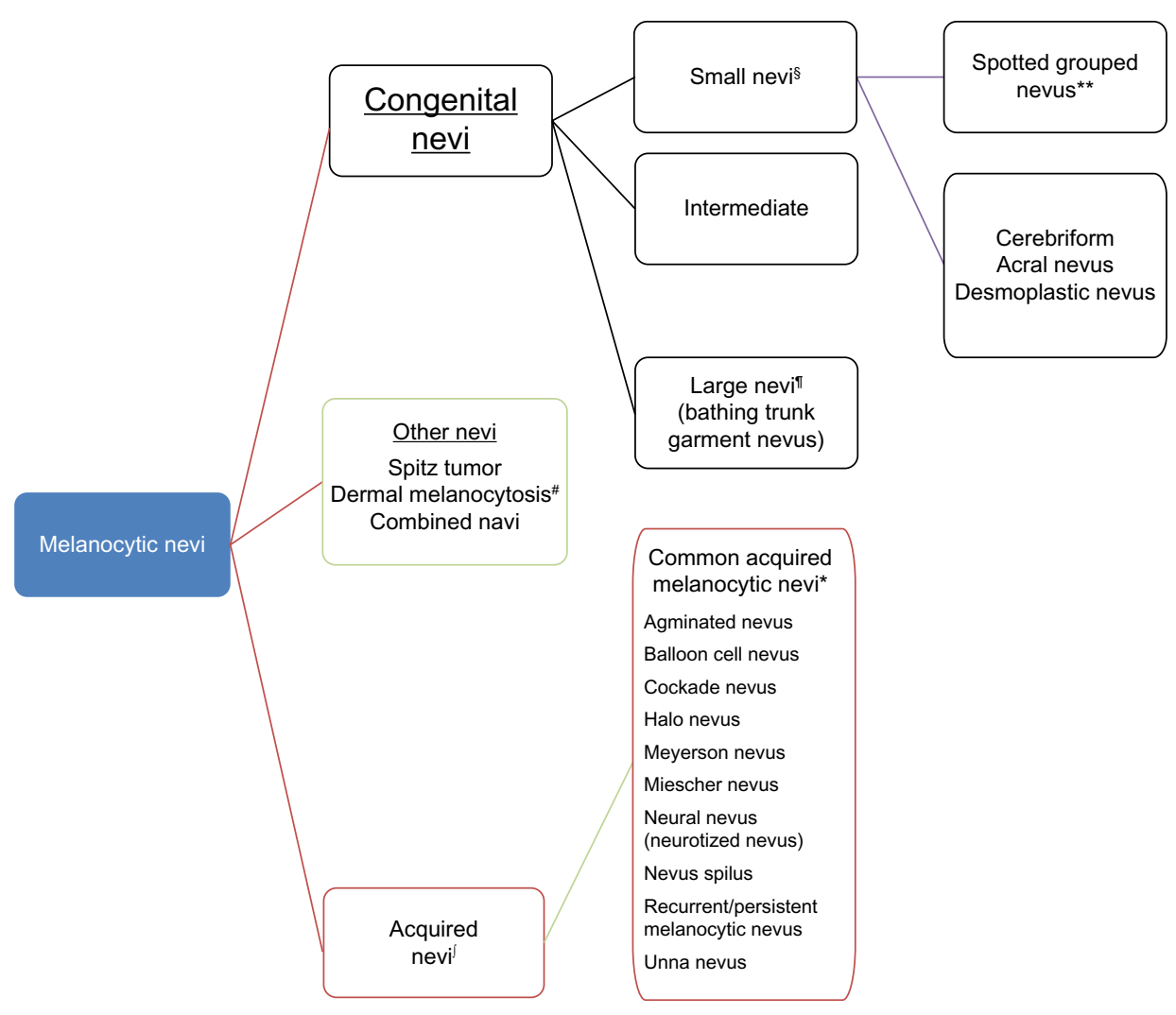

Figure I Classification of melanocytic nevi.

Notes: 'Site-specific classification (acral, nail, genital, and flexural nevi). ${ }^{*}$ Nevus of Ota/lto, Mongolian spots, blue nevi, plexiform pigmented spindle-cell nevi. §Small congenital melanocytic nevi (up to $1.5 \mathrm{~cm}$ in diameter), intermediate congenital melanocytic nevi $(1.5-19.9 \mathrm{~cm})$. "Large congenital melanocytic nevi ( $>20 \mathrm{~cm}$ ); the surface changes include smooth, cerebriform, rugose, verrucous, or lobular. *Types: epidermis (junctional), both epidermis and dermis (compound), or dermis only (dermal or intradermal). **Follicular congenital melanocytic nevi.

the pathologist as to whether the melanocytic proliferation is benign or malignant. ${ }^{3}$

Our aim is not to arrive at a consensus on these bewildering and evocative names, as there is no unanimity or litmus test to distinguish between unusual and tricky clinical and histologic melanocytic nevi, or between melanocytic proliferations and subtle melanomas. A wide array of invasive and noninvasive tests has been able to classify most acquired nevi into three common clinical types: junctional, compound, and dermal. We will be using the classification proposed previously and given in Figure 1 to categorize acquired melanocytic nevi. ${ }^{4}$

In the routine evaluation of melanocytic lesions, one is continually faced with the decision as to whether a lesion is benign or malignant. In approaching this problem, one has to apply a number of criteria for this interpretation, since no single criterion is sufficient. At present, there is no universal consensus as to which criteria should be included in this exercise, or the relative importance or relative weight of each criterion. It is certain that this latter exercise should take into consideration clinical information, organizational, cytological, and cell proliferation-related properties of the individual lesion. It must be emphasized that there are exceptions to each criterion, and the failure to consider this may result in both over- and underdiagnosis of melanoma. The authors believe that additional research and substantial efforts are needed to standardize the terminology of benign (and malignant) melanocytic neoplasms.

\section{Prevalence}

Some factors have emerged from studies that can predict the development of melanocytic nevi, the most important being sun exposure in childhood. ${ }^{5}$ The emergence of nevi is under strong genetic control, whereas environmental exposures affect the mean number of nevi. ${ }^{6}$ Nevi are seen more in boys than in girls, in White children more than in other ethnic groups, and in children with fair skin and blond or red hair. ${ }^{6-8}$ This latter finding has been contradicted in a study where children with red hair had more freckles but fewer melanocytic nevi. ${ }^{9}$ The use of a sunscreen reduces the development of new nevi on intermittently sun-exposed body sites, particularly in freckled children. ${ }^{10}$ Neonatal phototherapy is 
a strong risk factor for nevus development in childhood. ${ }^{11}$ Experimentally, ultraviolet radiation produces transient melanocytic activation. ${ }^{12}$

The genetic control of nevi does not appear to be related to changes in the CDKN2A gene, but a loss of heterozygosity is present, which may suggest that some are precursors of melanoma. ${ }^{13,14}$ Clinical confirmation of this transformation, however, can be seen only in those with a familial predisposition.

\section{Pathogenesis and course of melanocytic nevus}

Melanocytes seem to originate from pluripotent cells that migrate from the neural crest to the skin via the paraspinal ganglia and their peripheral nerves and become terminally differentiated after migration to the local microenvironment of the dermis and basal layer of the epidermis. Beyond establishing the embryonic origin of melanocytic nevi from neural crest-derived cells, the histogenesis of these melanocytic proliferations has not been adequately elucidated. The conventional viewpoint is that nevi arise from proliferation of intraepidermal melanocytes within junctional nests or theques. According to this model, nevus cells are considered a morphological variant of melanocytes that have assumed a morphology that is more epithelioid and less dendritic. With evolution of the lesions, it is held that cells "drop off" (Abtropfung of Unna) into the dermis. The Abtropfung hypothesis derives from cross-sectional observations correlating histological findings in nevi with chronological aging.

Unna's concept of Abtropfung ("dropping off") has been challenged in recent times, ${ }^{15,16}$ although the higher reactivity of proliferating cell nuclear antigen in junctional and compound nevi than in intradermal nevi supports the epidermal origin of acquired melanocytic nevi. ${ }^{17}$ Another hypothesis is that of the melanocyte differentiation pathway, which is an attempt to explain the origin of melanocytes and their subsequent upward migration into the epidermis, the reverse of Abtropfung. ${ }^{18,19}$ Zalaudek et al have put forward another theory based on dermoscopy that involves neither of these theories of pathogenesis. ${ }^{20}$

A reasonable hypothesis regarding the natural history of melanocytic nevi is that they arise as a lentiginous (ie, lentigo-like) proliferation of single-cell units along the basal zone of elongated and hyperpigmented rete ridges. At some point thereafter, the melanocytes undergo a morphological transition into the epithelioid nevus cells, with their propensity to aggregate as junctional nests (junctional nevus).
Following this stage of development as a junctional nevus, further cellular development and proliferation results in the migration or "dropping off" of nevus cells and their organization into nests within the papillary dermis (compound nevus). According to this generally accepted model, eventually all intraepidermal proliferation of melanocytes ceases, and the nevus becomes entirely intradermal (dermal nevus). Nevus cells residing within the dermis have reduced proliferative and metabolic activity, except for the formation of melanosomes. With the decline of replication, the nevus cell population is gradually replaced by mesenchymal elements, including fibrous matrix, glycosaminoglycans, and adipose tissue. Most dermal nevi are believed to undergo progressive involution, some eventuating as acrochordons, and others shedding. This is reflected in the course of the disease, as with advancing age, there is a progressive decrease in the number of nevi; thus, whereas the number of nevi in young adults varies from approximately 15 to 40 , this decreases markedly over the age of 50 years. ${ }^{21}$

\section{Clinical features}

Melanocytic nevi are well circumscribed, round to ovoid lesions, with regular and well defined borders. Although most are diagnosed clinically, a new classification system for nevi was proposed in 2007, based on dermoscopic features. ${ }^{22,23}$ The categories included in this are globular (congenital), reticular (acquired), starburst (Spitz/Reed), blue (homogeneous), and site-related nevi, and those with special features, such as halo, eczematous, combined, ${ }^{24}$ and recurrent nevi. ${ }^{22} \mathrm{~A}$ clinical and histological tabulation (Tables 1 and 2) is provided for the CAMN; although, in expert hands, dermoscopy may be equally effective in accurate diagnosis.

The junctional nevus is a macular lesion with slight accentuation of skin markings (Figure 2). The dermoscopic

Table I Clinical classification of common acquired melanocytic nevi

\begin{tabular}{|c|c|c|c|}
\hline & Junctional nevus & Compound nevus & Dermal nevus \\
\hline Size & 2-5 mm macule & 3 to $6 \mathrm{~mm}$ papule & $\begin{array}{l}\text { 3-6 mm papule, } \\
\text { dome-shaped or } \\
\text { papillomatous }\end{array}$ \\
\hline Onset & $\begin{array}{l}\text { Childhood, } \\
\text { adolescence }\end{array}$ & $\begin{array}{l}\text { Childhood, } \\
\text { adolescence, } \\
\text { third decade }\end{array}$ & $\begin{array}{l}\text { Onset first, } \\
\text { second, third } \\
\text { decades or later }\end{array}$ \\
\hline Shape & $\begin{array}{l}\text { Round, oval, } \\
\text { symmetrical }\end{array}$ & $\begin{array}{l}\text { Round, oval, } \\
\text { symmetrical }\end{array}$ & $\begin{array}{l}\text { Round, oval, } \\
\text { symmetrical }\end{array}$ \\
\hline Borders & $\begin{array}{l}\text { Well defined, } \\
\text { regular borders }\end{array}$ & $\begin{array}{l}\text { Well defined, } \\
\text { regular borders }\end{array}$ & $\begin{array}{l}\text { Well defined, } \\
\text { regular borders }\end{array}$ \\
\hline Color & $\begin{array}{l}\text { Homogeneous } \\
\text { brown, dark brown }\end{array}$ & $\begin{array}{l}\text { Homogeneous } \\
\text { brown, dark brown }\end{array}$ & $\begin{array}{l}\text { Light brown to } \\
\text { flesh tones }\end{array}$ \\
\hline
\end{tabular}


Table 2 Histopathologic features of common acquired melanocytic nevi

\begin{tabular}{|c|c|c|c|}
\hline & Junctional nevus & Compound nevus & Dermal nevus \\
\hline Symmetry & Yes & Yes & Yes \\
\hline Borders & Well circumscribed & Well circumscribed & Well circumscribed \\
\hline \multicolumn{4}{|l|}{ Histology } \\
\hline Junctional nesting & Regular & Regular & Dome-shaped or papillomatous \\
\hline $\begin{array}{l}\text { Morphology } \\
\text { of nests }\end{array}$ & $\begin{array}{l}\text { Uniform size, shape, and placement } \\
\text { of nests }\end{array}$ & $\begin{array}{l}\text { Uniform size, shape, and placement } \\
\text { of nests }\end{array}$ & $\begin{array}{l}\text { Orderly arrangement of nevus cells } \\
\text { in the dermis }\end{array}$ \\
\hline Degree of cohesion & Cohesive nests at tips of rete ridges & Cohesive nests at tips of rete ridges & \\
\hline Site of nevus cells & Basal layer & $\begin{array}{l}\text { Nevus cells often confined to papillary } \\
\text { or superficial reticular dermis }\end{array}$ & $\begin{array}{l}\text { Nevus cells often confined to papillary } \\
\text { or superficial reticular dermis }\end{array}$ \\
\hline Type of cells & Epithelioid cells & $\begin{array}{l}\text { Transition from epithelioid } \\
\text { to lymphocytoid to spindled cells } \\
\text { with dermal descent }\end{array}$ & $\begin{array}{l}\text { Transition from epithelioid } \\
\text { to lymphocytoid to spindled cells } \\
\text { with dermal descent }\end{array}$ \\
\hline
\end{tabular}

features of a junctional nevus shows a uniform pigment network thinning out towards the periphery. Compound nevi show variable degrees of elevation and have a general somewhat lighter shade of brown than do junctional nevi (Figure 3). Dermoscopically, they are characterized by a globular architecture with multiple round to ovoid globules, sometimes forming a cobblestone pattern. Dermal nevi are usually more elevated and are a lighter shade of brown or even skin-colored compared with compound nevi (Figure 4). The dermoscopic features of an intradermal nevus predominantly consist of focal globules or globular-like structures. In addition, there may be pale to whitish structureless areas and fine linear or comma vessels. Occasionally a patient may have lesions of all three types which typify the theory (Figure 4). In addition to clinical and dermoscopic overlap amongst all three types of nevi, dermal nevi may be papillomatous with pseudo-horn cysts. Some nevi, especially acquired "congenital-appearing" nevi, contain hairs that are coarse and dark compared with those in the surrounding skin (Figure 5).

The recurrent (persistent) nevus is defined as the appearance of macular pigmentation within the confines of the clinical scar of a previously biopsied (usually by shave

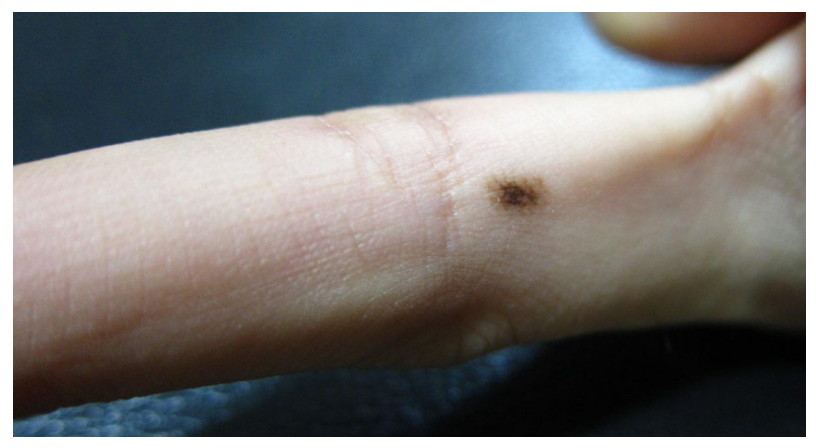

Figure 2 Macular junctional melanocytic nevi showing increased skin markings. technique) melanocytic nevus, usually after about 6 weeks to 6 months (Figure 6).

\section{Pathology}

It is generally accepted that all nevi should be submitted for histological examination for medicolegal reasons. In a recent study, $2.3 \%$ of clinically diagnosed benign nevi were microscopically diagnosed as malignant tumors, either melanomas or basal or squamous cell carcinomas. ${ }^{25}$ Although the $B R A F$ mutation is common in melanomas, it is also found in a significant number of benign nevi. ${ }^{26,27}$ This finding raises doubts about its relevance in melanoma development. Thus, melanoma development in melanocytic nevi is probably not as common as it is believed.

It has been customary to refer to the cells comprising a melanocytic nevus as "nevus cells" or "nevomelanocytes." Nevus cells are melanocytes which have lost their long dendritic processes due to an adaptive response associated with the formation of nests of cells. ${ }^{25}$ As this change cannot usually be appreciated in hematoxylin and eosin-stained

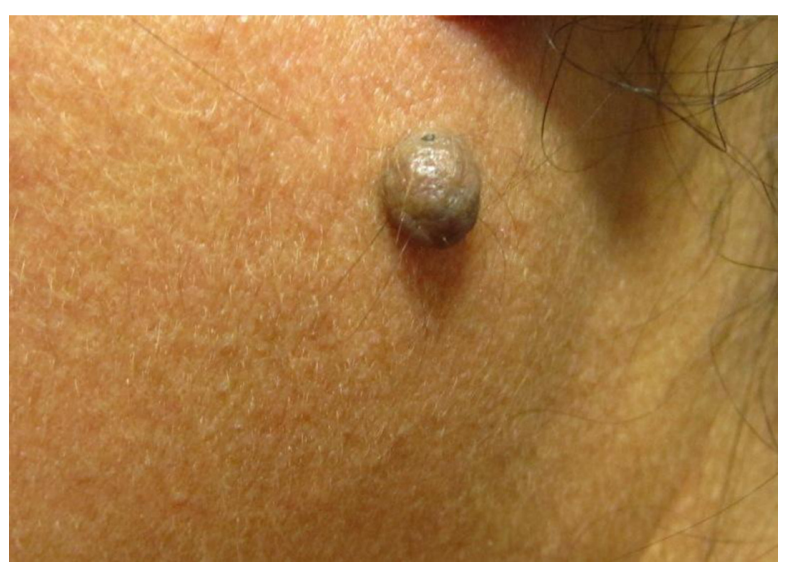

Figure 3 Raised pigmented papular lesion pathognomic of a compound melanocytic nevi. 


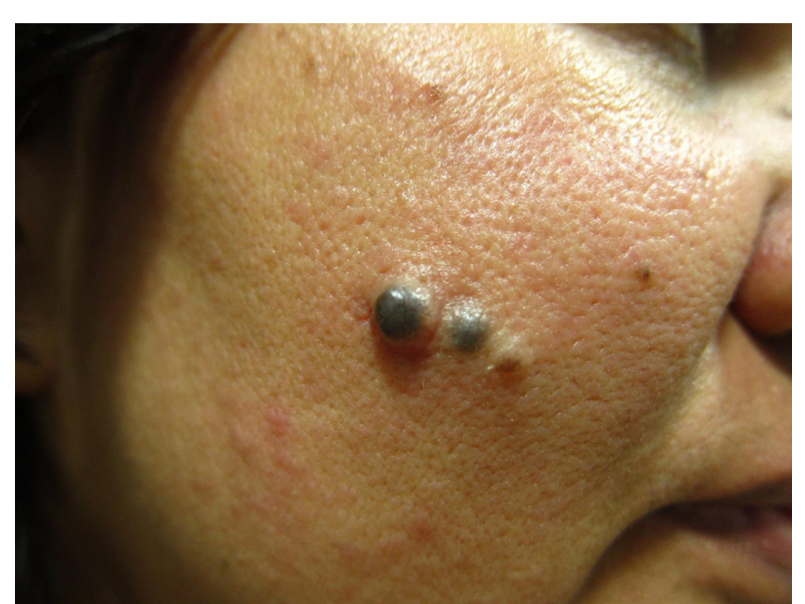

Figure 4 The three stages of melanocytic nevi, with loss of pigment and eventual resolution of lesion which mirrors the "Abtropfung" theory.

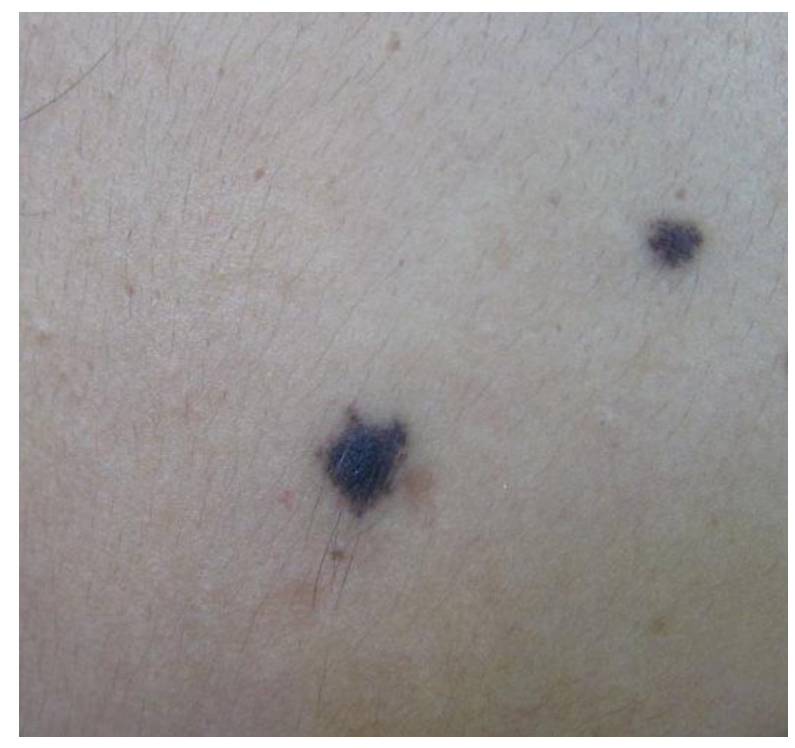

Figure 5 Compound nevi with "hair" emanating from the lesions, such lesions tend to recur after removal.

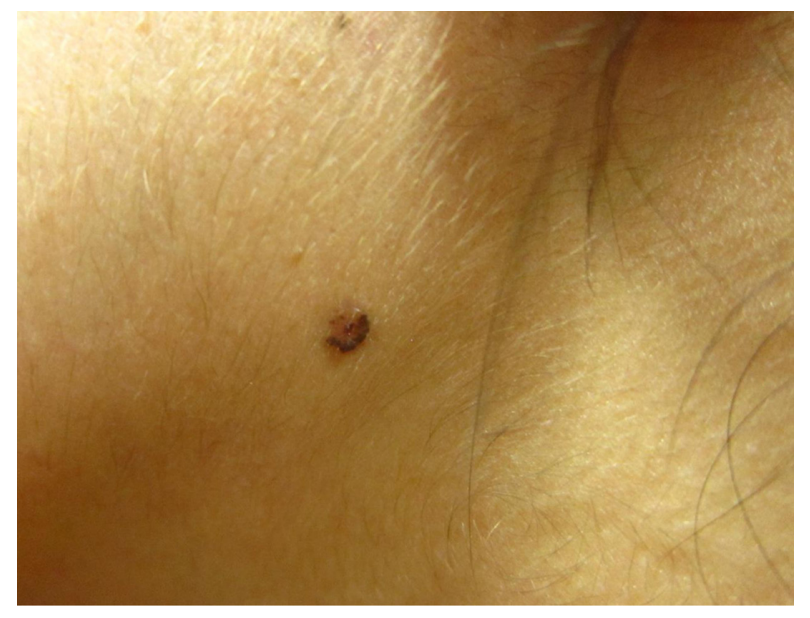

Figure 6 Recurrent nevus seen 6 months after surgical excision. preparations, it has been suggested that all cells in melanocytic nevi (epidermal and dermal) should be referred to as melanocytes. ${ }^{28}$

Melanocytic nevi contain intraepidermal or dermal collections of nevus cells or both. The cells within the junctional nests have round, ovoid, or fusiform shapes and are arranged in cohesive nests. ${ }^{4}$ With the notable exception of the unusual amelanotic variants, these cells contain melanin. ${ }^{4}$ In the superficial dermis, the cells have an epithelioid cell topography and contain amphophilic cytoplasm with granular melanin. The nuclei have uniform chromatin with a slightly clumped texture. Deeper in the dermis, there is a diminished content of cytoplasm, and the cells resemble lymphocytes and are arranged in linear cords. There may be a further transition to cells separated by fine connective tissue and assuming a spindled configuration, similar to fibroblasts or Schwann cells.

The "maturation" of melanocytes is accompanied by an alteration in the antigens they express. Cells in the junctional layer contain S100 protein and sometimes one or more of the melanoma-associated antigens (including $\mathrm{NKI} / \mathrm{C} 3$ and HMB-45), but usually only S100 protein is expressed by dermal nevus cells. ${ }^{29}$

\section{Treatment}

The treatment of CAMN is in most scenarios dictated by cosmetic necessity, ${ }^{30}$ and thus before embarking on such a procedure, the clinician should be sure about the possibility of melanoma or dysplasia. Although dermoscopy ${ }^{23,24}$ in trained hands is a good noninvasive choice, it must be remembered that in doubtful cases, a biopsy is probably the only certain way of confirming dysplasia. With greater emphasis being given to cosmetic results and because of an ever increasing workload, a number of "faster and less traumatizing" techniques have been introduced in the treatment and diagnosis of atypical nevi, including punch, shave, and "scoop shave" biopsies. However, it must be remembered that only a complete scalpel excision of all clinically atypical nevi permits the histological assessment of the entire lesion, while the aim of cosmetic surgery is largely removal of the visible lesion and is thus largely incomplete. ${ }^{31}$

Laser removal of CAMN is itself controversial since no specimen is submitted for tissue diagnosis and margin assessment. ${ }^{30,32}$ Conversely, the gold standard technique for removal of melanocytic nevi, which is excision followed by histological examination, results in a scar that is an undesired cosmetic outcome. The issue of melanoma arising as a consequence of laser therapy is debatable..$^{30,32}$ Although some 
believe that selective destruction of abnormal melanocytes is a means for reducing the number of cells at risk for malignant transformation, it is also possible that laser or other treatments may inadvertently stimulate transformation to melanoma. There have been reports of histological atypia (pseudomelanoma) in patients with melanocytic nevi that were treated by $\mathrm{CO}_{2}$ lasers as well as lasers for hair removal. ${ }^{33}$ Racial differences probably also need to be taken into consideration, as in Asians, the incidence of melanoma has been reported to be between 0.2 and 2.2 per 100,000, much lower than among Whites. ${ }^{34}$ Furthermore, the most common sites for the development of melanoma among people with skin of color are areas not directly exposed to the sun, such as palmar, plantar, subungual, and mucosal surfaces. ${ }^{34}$ This may account for the liberal use of lasers for the treatment of melanocytic nevi in Asian countries on the facial skin. However, it must be pointed out that malignant transformation takes time, and if the patient goes to an oncosurgeon or oncologist, it may not always reflect as long-term complications in dermatological practice. This is exemplified by the development of carcinoma bladder in patients of pemphigus on cyclophosphamide, wherein it takes 15 years to develop the complication ${ }^{35}$ and rarely presents to the treating dermatologist.

There are other issues regarding the use of pigmentspecific lasers for CAMN. The smaller and thinner lesions (junctional nevus) are typically more treatment-sensitive. ${ }^{30,32}$ With deeper lesions (compound and dermal nevus), complete eradication is much more difficult, and recurrence is common. ${ }^{30,32}$ Laser therapy decreases the number of the pigmented nevomelanocytic cells in the papillary dermis, but is unlikely to treat deep-seated non-pigmented cells that are closely associated with adnexal structures. This has been demonstrated histologically as persistent nevomelanocytic nests in the mid papillary and deeper dermis at depths of $0.16-0.44 \mathrm{~mm}^{30,32}$

Although radiofrequency and electrocautery are commonly used for removing CAMN, the nonspecific thermal damage induced by these techniques and the consequent cosmetic results do not justify their use in CAMN, removal of which is largely a cosmetic concern. Thus, our focus will be on surgical removal and the use of lasers.

\section{Surgical excision}

The technique of surgical excision is probably the oldest and involves various techniques like shave excision, round excision, deep excision, and razor-blade excision. ${ }^{36-39}$ The most common technique used is the razor-blade shave technique. ${ }^{36}$ This entails the use of a slightly curved classic razor blade to shave and remove the exophytic part of a skin lesion and part of the intradermal structure down to the papillary dermis. ${ }^{36,39}$ The existing data suggest that although it may have a favorable cosmetic outcome, issues of recurrence and histological confirmation have not been adequately addressed. This is more so as the deeper nevus cells can never be reliably removed. ${ }^{30,31}$

There are certain prerequisites while using the aforesaid techniques, the most important being the depth achieved vis a vis the type of nevi. For junctional nevi, a shave excision may suffice, ${ }^{36}$ but for the deeper compound and intradermal nevi, ${ }^{37}$ a modification may be required to enable a deeper excision. ${ }^{37}$ Another modification that has been suggested involves excision with a number 15 scalpel blade, $2 \mathrm{~mm}$ beyond the limits, with incision to the full depth of the dermis. ${ }^{38}$ In spite of all these modifications, the recurrence rate is high, and it is not unreasonable to believe that a longer follow-up would lead to more recurrences (Table 3 ). Immediate patient satisfaction, however, is good, even though there is a scar that is perceptible. ${ }^{36}$ The high recurrence rate $(13 \%-26 \%)$ of this largely "blind" procedure is the reason to use the technique with caution.

It is important to consider the histopathological perspective $^{31}$ in the technique of shave excisions in melanocytic nevi. The use of the various methods ( punch, shave, and "scoop shave" biopsies) $)^{36-40}$ have a major limitation as only a part of the lesion is available for histological assessment. ${ }^{31}$ Cohen et $\mathrm{al}^{41}$ found residual nevus in $24.9 \%$ of re-excisions of atypical melanocytic nevi that were initially biopsied with either the shave or punch technique. As shave and punch biopsies contain only the central portion of the lesion, the area of interface between the melanocytic lesion and normal skin

Table 3 Studies on surgical excision of common acquired melanocytic nevi

\begin{tabular}{|c|c|c|c|}
\hline Study & Method & Number & Comments \\
\hline $\begin{array}{l}\text { Ferrandiz } \\
\text { et al }{ }^{36}\end{array}$ & Shave excision & 204 nevi & $\begin{array}{l}\text { Recurrence seen in } 19.6 \% \\
\text { of cases at } 3 \text { months }\end{array}$ \\
\hline $\begin{array}{l}\text { Tursen } \\
\text { et }\left.a\right|^{38}\end{array}$ & $\begin{array}{l}\text { Round excision } \\
\text { technique }\end{array}$ & $\begin{array}{l}36 \text { papular } \\
\text { nevi }\end{array}$ & $\begin{array}{l}\text { Complete removal in } \\
\text { all cases }\end{array}$ \\
\hline $\begin{array}{l}\text { Gambichler } \\
\text { et } \mathrm{al}^{37}\end{array}$ & $\begin{array}{l}\text { Deep shave } \\
\text { excision } \\
\text { of macular } \\
\text { melanocytic nevi }\end{array}$ & $\begin{array}{l}77 \text { macular } \\
\text { melanocytic } \\
\text { nevi }\end{array}$ & $\begin{array}{l}12 \% \text { were incompletely } \\
\text { excised } \\
\text { Recurrence seen in } 13 \% \\
\text { at } 6 \text { months }\end{array}$ \\
\hline $\begin{array}{l}\text { Breuninger } \\
\text { et } \mathrm{al}^{39}\end{array}$ & $\begin{array}{l}\text { Conventional } \\
\text { excisions } \\
\text { (intracutaneous } \\
\text { butterfly } \\
\text { sutures) and } \\
\text { shave excisions }\end{array}$ & $\begin{array}{l}268 \text { nevi } \\
\text { versus } \\
403 \text { nevi }\end{array}$ & $\begin{array}{l}\text { Shave excisions resulted } \\
\text { in fewer complications } \\
(7.9 \% \text { versus } 15 \%) \text {, but } \\
\text { recurrences were more } \\
\text { frequent ( } 18.1 \% \text { versus } \\
6.0 \%)\end{array}$ \\
\hline
\end{tabular}


is absent. Thus, the evaluation of architecture is not possible. Shave biopsies that sample only the superficial aspect of the lesion do not allow for evaluation of maturation.

In compound dysplastic nevi, the junctional component often extends beyond the underlying dermal component (the "shoulder"), and trails off over several rete ridges. This corresponds to the clinical appearance of a central papule with fading edges that merge with the normal skin. To ensure complete removal, these lesions should be excised with a $2 \mathrm{~mm}$ clinically clear margin to ensure that the tapering junctional component is completely excised. In the study by Cohen et al, ${ }^{41}$ residual nevus was more often associated with punch than with shave biopsies, probably because the "shoulder" is more efficiently excised by shave biopsies. A recent study by Barr et $\mathrm{al}^{42}$ documented that $35.9 \%$ of atypical nevi show variations in the degree of atypia from one area to another.

Another issue is that when the pathologists receive partial biopsies of dysplastic nevi, there is a recommendation for a complete and adequate re-excision, with a specification of the precise margin in millimeters. This may be an issue for the dermatologists, as it can expose them to a litiginous situation in the case of an unfavorable outcome.

Thus, although a structured approach with deep excision in compound and dermal nevus is proposed, the skills of the operator cannot predict the chance of recurrence ${ }^{36-39,43}$ and the inadequate histological opinion can lead to medicolegal issues. ${ }^{31,41,42}$

\section{Lasers}

The lasers used for CAMN range from pigment-selective lasers to ablative lasers (Figure 7). The use of lasers in CAMN (moles) is complicated by many practical issues and scenarios which have to be properly understood before attempting this mode of therapy. ${ }^{29,44-46}$

\section{Principles of therapy}

Like any other indication, the use of lasers in pigmented lesions begins at the helm of laser physics and depends on the absorption spectra of the target chromophore, which is believed to be the melanocyte (melanosome). ${ }^{29,46}$ The spectrum of lasers used ranges from the green lasers (pulsed dye, Q-switched [Qsw], and neodymium [Nd]:yttrium aluminum garnet [YAG] 532) to the far-infrared lasers $\left(\mathrm{CO}_{2} 10,600 \mathrm{~nm}\right.$ and erbium [Er]:YAG 2,940 nm) (Figure 7).

Mid-infrared lasers (1,300-1,600 nm) such as some diode, Er, thallium, and the 1,320 nm emission line of $\mathrm{Nd}$ :YAG are moderately absorbed by water. These produce thermal damage in the epidermis, upper dermis, and/or middermis but do not specifically target melanin. ${ }^{32}$ In general, the best wavelength region for treating pigmented lesions is red and near-infrared (approximately 600-1,100 nm). ${ }^{32,44,45}$ This wave band combines the most selective absorption by melanin, with the deepest skin penetration.

The second important proviso is to minimize heat damage, which requires optimal setting of the pulse duration of the laser. A laser with a pulse duration less or equal to the thermal relaxation time (TRT) of the target tissue should be employed. This, in turn, depends on the size of the target tissue which dictates TRT. This ranges from 0.25 to $1.00 \mu \mathrm{sec}$ for the melanosome to $0.1 \mathrm{msec}(100 \mu \mathrm{sec})$ for the melanocyte. ${ }^{32}$ Although the nanosecond lasers (Qsw) have been conventionally used to treat pigmented lesions such as lentigines, freckles, and "nevus of Ota," the same principle cannot apply to CAMN. The geometry (and therefore the microscopic characteristics) of the lesion is important, and as the nevus is composed of melanocytes in aggregates (collectively of a size of $100 \mu \mathrm{m}$ in diameter) this corresponds to a TRT of about $10 \mathrm{msec},{ }^{32}$ thus accounting for the use of normal mode (msec) and far-infrared lasers to treat CAMN.

The third requirement is to achieve an adequate depth to target the chromophore for which the red (ruby $694 \mathrm{~nm}$, alexandrite $755 \mathrm{~nm}$ ) and near-infrared (QswNd:YAG 1,064 nm) lasers (approximately 600-1,100 nm) are ideal.

Based on these three principles, the devices useful for treating melanocytic lesions are of two basic classes: farinfrared skin resurfacing lasers and pulsed lasers/intense pulsed light (IPL) lasers. The pulsed lasers are further divided into long-pulse (msec) devices, which tend to target relatively large pigmented structures such as hair follicles and "nests" of nevus cells, and short-pulse (Qsw nsec lasers) devices, which are capable of targeting individual pigmented cells. ${ }^{32}$ Histologically, CAMN have both isolated nevo-melanocyte cells, and "nests," or clusters, of cells. ${ }^{32,44-46}$ Thus, a mixture of lasers targeting both should ideally be used, with the use of short (nsec) pulses and long ( $\mathrm{msec}$ ) pulses. This is the reason why melanocytic nevi are better treated with a combination of lasers.

Recent studies ${ }^{47}$ have used pulsed $\mathrm{CO}_{2}$, ostensibly to ensure ablation of the epidermis, followed by a Qsw frequencydoubled Nd:YAG, Qsw Nd:YAG, or a Qsw alexandrite laser. The logic employed in the use of combination lasers (normal mode and Qsw ruby laser, $\mathrm{CO}_{2}$ and Qsw alexandrite, $\mathrm{CO}_{2}$ and Qsw frequency-doubled Nd:YAG laser, $\mathrm{CO}_{2}$ and Qsw ruby laser) is to expose the otherwise unaffected, deep-sited 

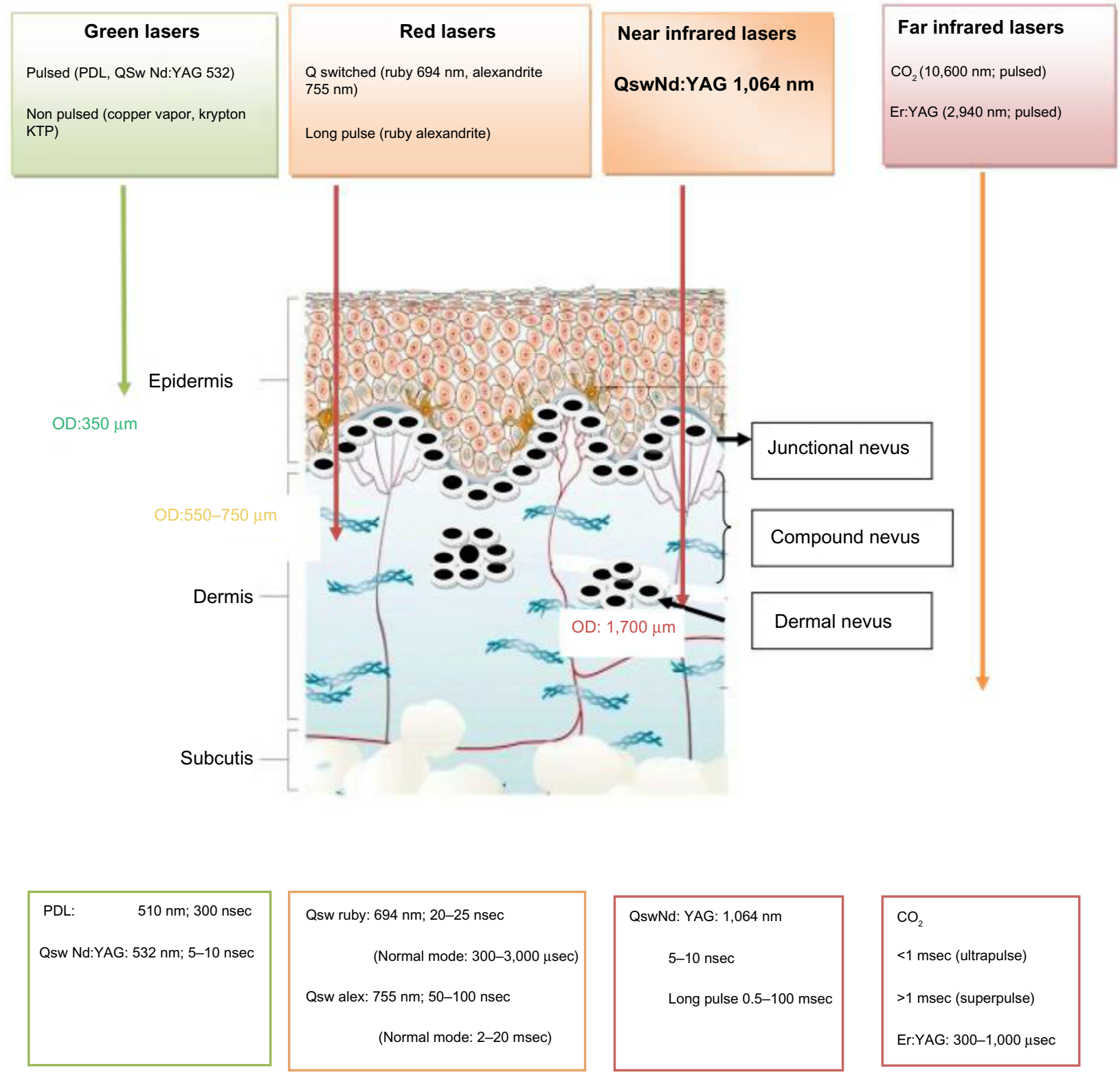

Figure 7 Classification of lasers used in common acquired melanocytic nevi.

Abbreviations: Er:YAG, erbium yttrium aluminum garnet; KTP, potassium titanyl phosphate; Nd:YAG, neodymium yttrium aluminum garnet; OD, optical penetration depth; PDL, pulsed dye laser; Qsw, Q-switched; alex, alexandrite.

nevomelanocytes to the pigment-specific laser. Nevus cells in the superficial dermis are additionally removed by the $\mathrm{CO}_{2}$ laser. Alternatively, for a smaller "mole" $(<1.5 \mathrm{~cm})$, a short-pulsed Er:YAG would be an ideal tool, as apart from the pulse duration $(300-1,000 \mu \mathrm{sec})$ the Er:YAG laser has a predictable depth $\left(5 \mu \mathrm{m} / \mathrm{J} / \mathrm{cm}^{2}\right)$, minimal thermal damage (20-30 $\mu \mathrm{m})$, and a high absorption coefficient of water (Er:YAG $12,800 \mathrm{~cm}^{-1} ; \mathrm{CO}_{2} 800 \mathrm{~cm}^{-1}$ ), and is thus capable of a far finer and safer superficial ablation, with minimal sequelae..$^{29}$ A comparison of various modalities at our center revealed that the combined or pulsed ablative method is better than using the Qsw lasers for CAMN. ${ }^{29}$

\section{Lasers and melanoma}

The controversy of laser treatment of melanocytic nevi emanates from the concept that laser irradiation may have the potential to induce malignant change in nevus cells. In-vitro studies of melanoma cells treated with Qsw lasers have found changes in cell surface integrin expression, with subsequent alteration of cell migration. ${ }^{48} \mathrm{~A}$ significant increase in p16INK4a in p16 positive cell lines following irradiation with Qsw laser light suggests that sub-lethal laser damage may increase DNA damage, leading to an increase in p16 expression. ${ }^{49}$ In clinical practice, benign appearing nevi that tend to recur following laser treatment 
may show newfound clinical and histologic atypia, referred to as pseudomelanoma. ${ }^{39,43}$ There has never been a report, however, of true malignant transformation of a benign pigmented lesion following laser treatment, ${ }^{50}$ which is epidemiologically low in the Asian skin type even without an intervention. ${ }^{34}$ Conversely, laser treatment of melanocytic lesions may decrease the risk of malignant transformation of a benign pigmented lesion simply by reducing the population of existing potentially premalignant cells. This is supported by a study where no significant malignant markers (such as proliferation cell nuclear antigen, pyrimidine dimers, 8-OHdG [8-hydroxy-2'-deoxyguanosine], and p53) were found following treatment of nevi with Qsw lasers. ${ }^{51}$

\section{Pigment-specific lasers (Table 4)}

The Qsw ruby, alexandrite, and 1,064 nm Nd:YAG lasers all have some efficacy in removing flat or slightly raised acquired nevi. ${ }^{30,52-54}$ As a rule of thumb, lighter nevi respond best to shorter wavelengths that maximize melanin absorption, while darker nevi typically respond to any wavelength within the melanin absorption spectrum. ${ }^{53,55}$ Also, the deeper intradermal and compound nevi do not respond to conventional dose settings of the Qsw lasers. ${ }^{53,55}$ Multiple treatments are frequently necessary for optimal lightening.

It is often not feasible to hope for complete resolution of nevi, and recurrence after laser treatment is common. ${ }^{55}$ This is because there is persistence of nevus cells containing little pigment located in the deeper dermis that are shielded from laser radiation by the more pigmented superficial cells. Also, Qsw laser radiation does not penetrate sufficiently to effectively treat thicker papillated or dome-shaped dermal nevi. ${ }^{53,55}$

This led to the use of microsecond and millisecond pigment-specific lasers for CAMN. ${ }^{55-59}$ Although the results were better than the nanosecond lasers, issues of recurrence have not been adequately addressed. ${ }^{55,56}$ So, while it makes sense to use a laser with a millisecond pulse duration to match

Table 4 Studies on use of pigment specific lasers on common acquired melanocytic nevi

\begin{tabular}{|c|c|c|c|c|c|}
\hline & Laser & Pulse duration & Number & Results & Comments \\
\hline Wang et $\mathrm{al}^{57}$ & $\begin{array}{l}755 \mathrm{~nm} \\
\text { alexandrite }\end{array}$ & $\begin{array}{l}\text { I00 } \mu \text { sec long- } \\
\text { pulsed mode }\end{array}$ & 53 lesions & $\begin{array}{l}38.9 \% \text { of patients had "excellent" results. } \\
\text { At } 4 \text { weeks post-treatment, } 92.5 \% \text { were } \\
\text { totally cleared, with } 26.4 \% \text { reporting } \\
\text { mild atrophy, and } 20.8 \% \text { reporting mild } \\
\text { post-inflammatory hypopigmentation }\end{array}$ & $\begin{array}{l}\text { No follow-up or histological } \\
\text { evaluation was done }\end{array}$ \\
\hline Alshami $^{58}$ & $\begin{array}{l}\text { Long-pulsed } \\
532 \mathrm{~nm} \\
\text { Nd:YAG }\end{array}$ & $20 \mathrm{msec}$ & 350 & $\begin{array}{l}\text { All nevi were completely removed, } \\
\text { with good to excellent cosmetic } \\
\text { results after only one session. } \\
\text { Recurrence was seen within } 2-6 \text { months } \\
\text { of laser treatment in } 25 \text { patients }\end{array}$ & $\begin{array}{l}\text { Long pulse is a preferred laser } \\
\text { mode for melanocytic nevi }\end{array}$ \\
\hline Sardana ${ }^{30}$ & Qsw Nd:YAG & nsec & 20 & $\begin{array}{l}75 \% \text { improvement } \\
\text { Four sessions }\end{array}$ & $\begin{array}{l}\text { Most lesions lightened but } \\
\text { were not removed }\end{array}$ \\
\hline Kim et $\mathrm{al}^{54}$ & Qsw Nd:YAG & nsec & 2,064 patients & $\begin{array}{l}70 \% \text { removed in one session } \\
30 \% \text { removed in three sessions }\end{array}$ & $\begin{array}{l}\text { The lesions were small. No } \\
\text { follow-up or histological } \\
\text { evaluation was performed }\end{array}$ \\
\hline Duke et $\mathrm{al}^{55}$ & $\begin{array}{l}\text { Normal-mode and } \\
\text { Qsw ruby laser } \\
\text { light }(694 \mathrm{~nm})\end{array}$ & Variable & $\begin{array}{l}\text { Benign, atypical, } \\
\text { and congenital } \\
\text { nevi }(3 \mathrm{I})\end{array}$ & Sixteen $(52 \%)$ of the nevi improved & $\begin{array}{l}\text { Complete histologic removal } \\
\text { of all nevomelanocytes was } \\
\text { not seen in any case }\end{array}$ \\
\hline $\begin{array}{l}\text { Westerhof } \\
\text { and Gamei }{ }^{56}\end{array}$ & $\begin{array}{l}\text { Qsw and normal } \\
\text { mode ruby laser }\end{array}$ & $\begin{array}{l}\text { nsec vs } \\
\text { msec }\end{array}$ & $\begin{array}{l}\text { Qsw f/b normal } \\
\text { mode }\end{array}$ & $\begin{array}{l}\text { I-3 sessions } \\
\text { Flat lesions responded completely. } \\
\text { Slightly elevated lesions showed } \\
\text { only a partial response }\end{array}$ & $\begin{array}{l}\text { Junctional nevus responded } \\
\text { the best to Qsw lasers }\end{array}$ \\
\hline Reda et $\mathrm{al}^{59}$ & $\begin{array}{l}\text { Alexandrite laser } \\
(755 \mathrm{~nm})\end{array}$ & $\begin{array}{l}\text { Normal mode } \\
(3 \mathrm{msec})\end{array}$ & 40 lesions & $\begin{array}{l}\text { At the end of } 4 \text { months, } 76.92 \% \text { nevi } \\
\text { attained moderate to significant lightening } \\
\text { of color, } 19 \% \text { nevi had their color } \\
\text { matching that of the surrounding skin }\end{array}$ & $\begin{array}{l}\text { Complete removal was not } \\
\text { seen }\end{array}$ \\
\hline $\begin{array}{l}\text { Rosenbach } \\
\text { et } \mathrm{al}^{52}\end{array}$ & $\begin{array}{l}\text { Qsw alexandrite } \\
(755 \mathrm{~nm}) \text { and } \\
\text { Nd:YAG } \\
(1,064 \mathrm{~nm})\end{array}$ & $\begin{array}{l}\text { Comparison of } \\
\text { two nsec } \\
\text { lasers }\end{array}$ & NA & $\begin{array}{l}\text { Significant reduction after } 3 \text { sessions } \\
\text { Qsw alexandrite laser produced slightly } \\
\text { better results using the parameters } \\
\text { outlined }\end{array}$ & $\begin{array}{l}\text { Objective evaluation with } \\
\text { reflectance spectrometry and } \\
\text { histology was performed }\end{array}$ \\
\hline $\begin{array}{l}\text { Vibhagool } \\
\text { et } \mathrm{al}^{53}\end{array}$ & $\begin{array}{l}\text { Qsw ruby laser } \\
(694 \mathrm{~nm}, 28 \mathrm{nsec})\end{array}$ & nsec & $\begin{array}{l}\text { I8 small } \\
\text { melanocytic } \\
\text { nevi }\end{array}$ & $\begin{array}{l}\text { Twelve lesions (67\%) showed a complete } \\
\text { response and six lesions (33\%) } \\
\text { had a partial response }\end{array}$ & $\begin{array}{l}\text { The Qsw ruby laser is effective } \\
\text { in removing small melanocytic } \\
\text { nevi, but recurrence was seen }\end{array}$ \\
\hline
\end{tabular}

Abbreviations: NA, not applicable; Nd:YAG, neodymium yttrium aluminum garnet; Qsw, Q-switched; f/b, followed by. 
Table 5 Studies on ablative lasers for treating acquired common acquired melanocytic nevi

\begin{tabular}{|c|c|c|c|c|c|}
\hline & Laser & Pulse duration & Number & & Comments \\
\hline Sardana ${ }^{30}$ & Er:YAG & $300 \mu \mathrm{sec}$ & 20 nevi & $\begin{array}{l}\text { I00\% improvement } \\
\text { One session }\end{array}$ & $\begin{array}{l}\text { A pulsed Er:YAG shows a predictable } \\
\text { depth and improvement }\end{array}$ \\
\hline Sardana ${ }^{30}$ & $\begin{array}{l}\mathrm{Up} \mathrm{CO}_{2} \\
\text { (ultrapulse) }\end{array}$ & $\begin{array}{l}<\mathrm{I} \mathrm{msec} \\
(250 \mu \mathrm{sec})\end{array}$ & 20 nevi & $\begin{array}{l}100 \% \text { improvement } \\
\text { One session }\end{array}$ & $\begin{array}{l}\text { Pulsed } \mathrm{CO}_{2} \text { shows a predictable } \\
\text { depth and improvement }\end{array}$ \\
\hline Sardana $a^{30}$ & $\begin{array}{l}\text { Er:YAG/Up } \mathrm{CO}_{2} \mathrm{f} / \mathrm{b} \\
\text { Qsw Nd:YAG }\end{array}$ & Variable & 20 nevi & $\begin{array}{l}\text { I-3 sessions } \\
\text { With } 75 \% \text { improvement }\end{array}$ & $\begin{array}{l}\text { The thermal damage is less due to } \\
\text { the two-step procedure }\end{array}$ \\
\hline $\begin{array}{l}\text { Hammes } \\
\text { et a }\left.\right|^{61}\end{array}$ & $\begin{array}{l}\mathrm{CO}_{2}, \mathrm{Er}: \mathrm{YAG} \\
\text { and ruby }\end{array}$ & Variable & $\begin{array}{l}130 \\
\text { intradermal } \\
\text { nevi }\end{array}$ & $\begin{array}{l}2.3 \% \text { of intradermal nevi recurred as a } \\
\text { pigmented macule, while } 6.9 \% \text { reappeared } \\
\text { as a papule or nodule (volume recurrence). } \\
88 \% \text { of the patients were very satisfied } \\
\text { with the result }\end{array}$ & $\begin{array}{l}\text { Combination of lasers is needed for } \\
\text { intradermal nevi }\end{array}$ \\
\hline $\begin{array}{l}\text { Baba } \\
\text { and } \mathrm{Ba}^{60}\end{array}$ & Er:YAG & $300 \mu \mathrm{sec}$ & 28 lesions & $96 \%$ response & $\begin{array}{l}\text { Short-pulse } \\
\text { Er:YAG is an effective modality for } \\
\text { melanocytic nevi }\end{array}$ \\
\hline
\end{tabular}

Abbreviations: Er:YAG, erbium yttrium aluminum garnet; Nd:YAG, neodymium yttrium aluminum garnet; Qsw, Q-switched; Up, ultrapulse; f/b, followed by.

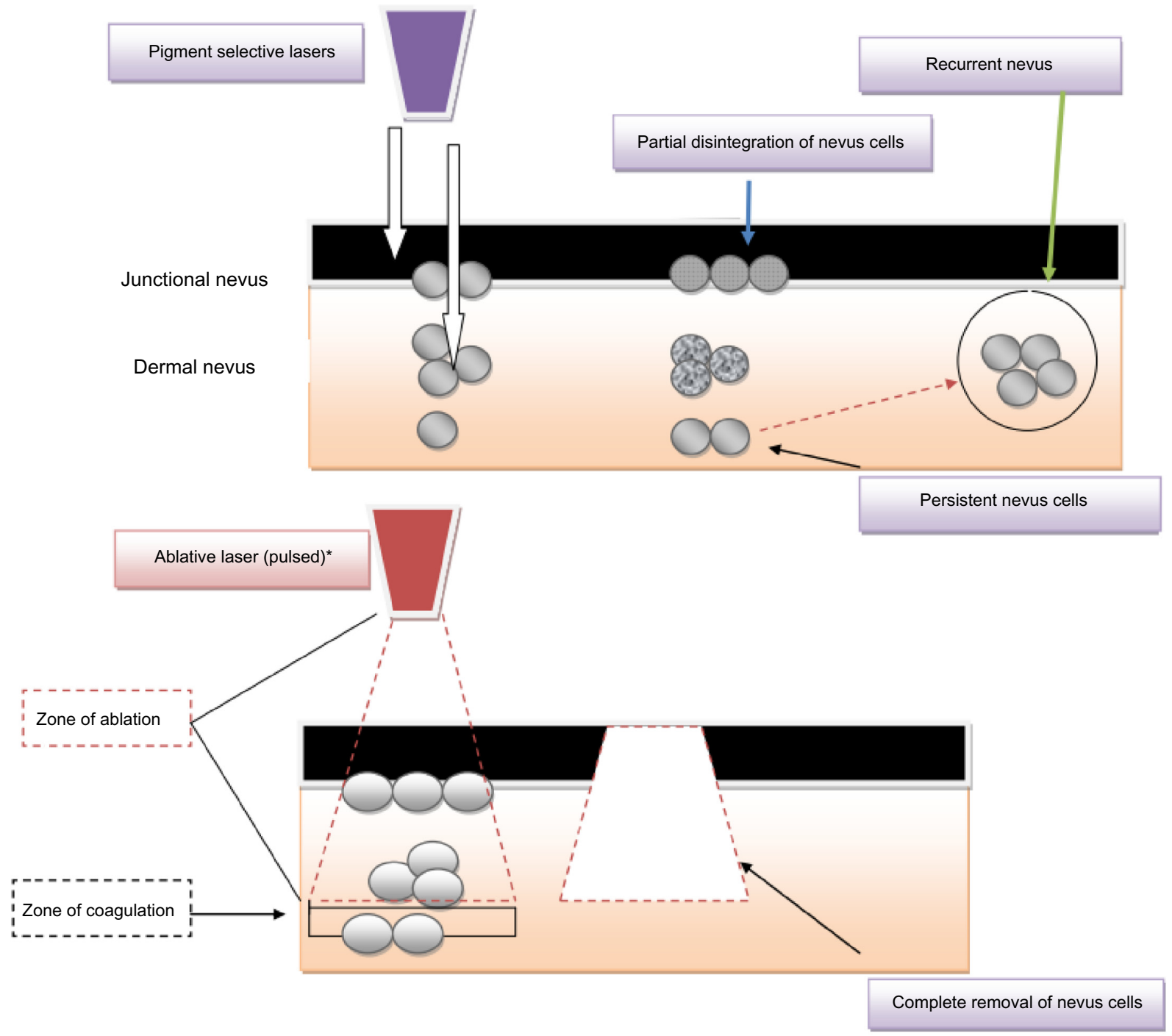

Figure 8 A diagrammatic comparison of the effect of pigment-specific lasers and ablative lasers in common acquired melanocytic nevi. The lack of persistent nevus cells with ablative lasers leads to less chance of recurrent nevus, which is a distinct possibility with pigment-specific lasers.

Note: *Er:YAG (200-300 msec, pulse duration)/ultrapulse $\mathrm{CO}_{2}(<\mathrm{l} \mathrm{msec}$, pulse duration).

Abbreviations: Er:YAG, erbium yttrium aluminum garnet. 
the TRT of nevus cells, the increased energy may lead to a high thermal confinement, and the rise in peak temperature may result in scarring.

\section{Ablative lasers (Table 5)}

Although the traditional ablative lasers (Er:YAG and $\mathrm{CO}_{2}$ ) had issues due to increased coagulation attributable to high thermal damage, the newer pulsed lasers have been programmed to achieve a pulse duration less than the TRT of skin $(<1 \mathrm{msec})$.
Studies using the short-pulsed Er:YAG lasers ( $\mu$ sec pulse) have been reported to be quite effective in removing flat or slightly palpable melanocytic nevi. ${ }^{30,60,61}$

\section{Which lasers should be used for acquired melanocytic nevi?}

The histological variables of a CAMN are such that any laser has to factor in the depth, size of individual nests, and the variability of pigment in the nevus cells, especially in dermal

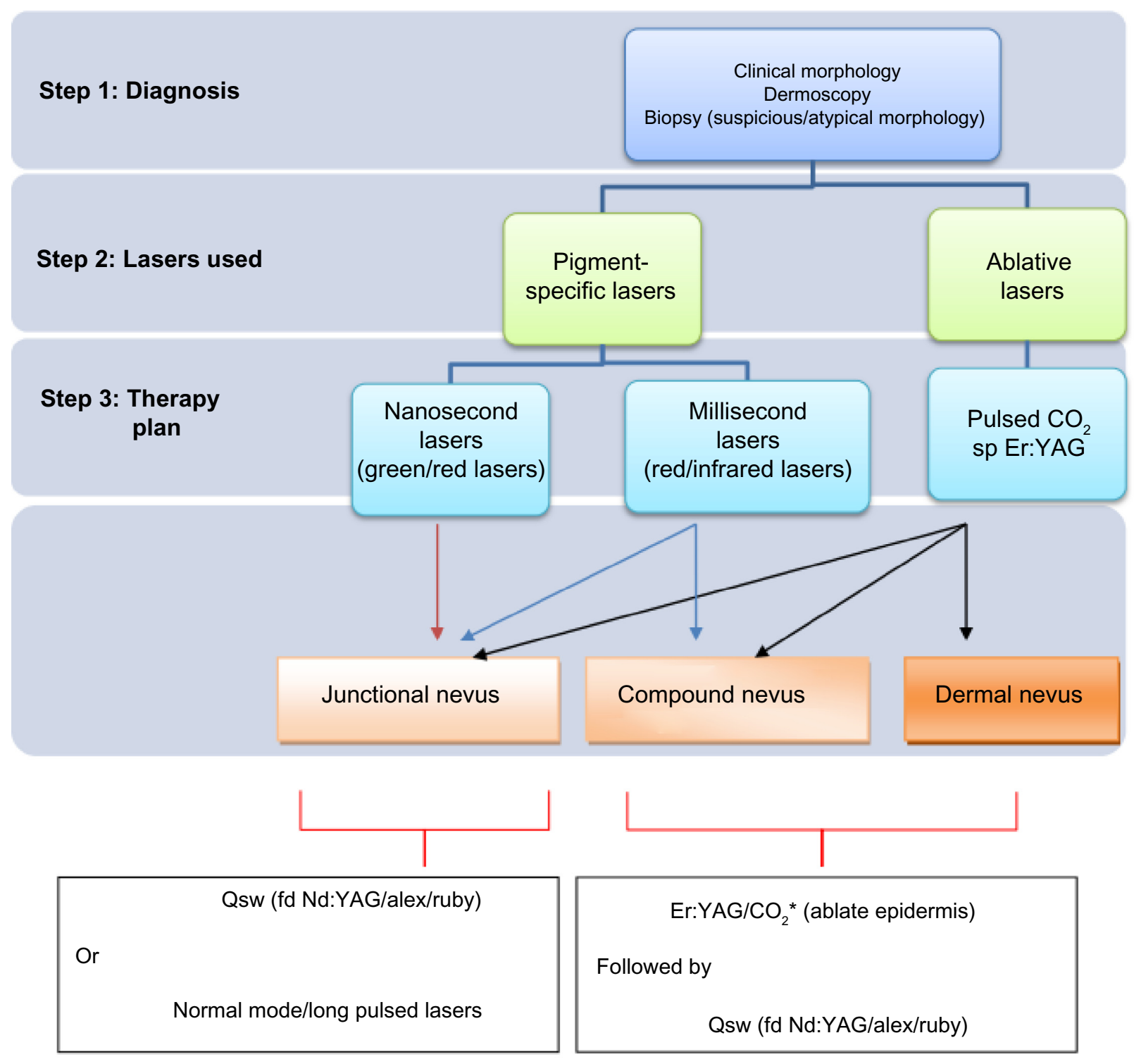

Step 4: posttreatment protocol

\section{Biopsy after 4 weeks}

Figure 9 An algorithm for management of common acquired melanocytic nevi with lasers.

Note: *For most nevi, ablative lasers can remove the lesions without the use pigment-specific lasers.

Abbreviations: alex, alexandrite; Er:YAG, erbium yttrium aluminum garnet; fd, frequency-doubled; Nd:YAG, neodymium yttrium aluminum garnet; Qsw, Q-switched; Sp, shortpulsed. 
nevi. Most of the present data are derived from the experience gained while using lasers for congenital melanocytic nevi. ${ }^{32,50,62,63}$ The effectiveness of lasers was believed to be due to the formation of superficial dermal fibrosis that hides the residual deep layer of nevus cells. ${ }^{62}$

With pigment-specific lasers, there is a thermal acoustic effect with partial disintegration of pigment, and due to the variable depth achieved, some nevus cells may not be targeted (Figure 8). On the contrary, ablative lasers remove the target cells effectively, and the depth can be achieved by adjusting the dose. ${ }^{46,64}$ The Er:YAG laser ablates approximately 5-50 $\mu \mathrm{m}$ of tissue with each joule per square centimeter, the thermal injury per pass is $15-50 \mu \mathrm{m}$, and there is a predictable depth achieved with ablation of the nevi. ${ }^{46,64}$ The pulsed $\mathrm{CO}_{2}$ laser has a higher ablation depth of 20-60 $\mu \mathrm{m}$ per pass and causes thermal coagulation ranging from 75 to $150 \mu \mathrm{m}$ per pass. ${ }^{46,64}$ This high thermal coagulation may be advantageous in achieving complete destruction of nevus cells and preventing recurrence. Thus, both these lasers, if modulated correctly, can be used for removing CAMN with controlled thermal damage (Figure 8).

Combining various lasers ${ }^{30,47,55,56,61}$ has been shown to achieve better results while treating CAMN. One approach was suggested by Kono et al, ${ }^{63}$ where a combination of Qsw and long-pulse laser passes was used in each treatment session. Kono's technique can be pursued using ruby, alexandrite, and/or Nd:YAG lasers, all of which selectively target dermal pigmented cells and are available in both long-pulse and Qsw versions. ${ }^{63}$ A high-power $810 \mathrm{~nm}$ pulsed diode laser, delivered with cold sapphire contact cooling, or a red-NIR filtered IPL can also be used for the long-pulse device. ${ }^{32}$

The basic principle that should guide the clinician is that, due to the variable histology of CAMN, a combination of lasers are used. An approach that we routinely follow is using the Qsw lasers for junctional nevi, Er:YAG/ultrapulse $\mathrm{CO}_{2}$ followed by Qsw Nd:YAG for compound nevi, and ablative lasers for dermal nevi (Figure 9). A basic principle that should dictate therapy is to remove the epidermis, especially in compound and dermal nevi. This can be achieved either by a high-fluence Qsw laser or using Er:YAG or pulsed $\mathrm{CO}_{2}$ lasers prior to the use of long-pulse laser and Qsw laser passes. ${ }^{47}$ As the longer wavelengths and longer pulse widths tend to require higher fluence for efficacy, there is a risk of thermal damage, and thus "pulse stacking" (repeating pulses in the same site) should be avoided.

\section{Conclusion}

Recent studies have suggested that significant increases in melanocytic nevi counts in preschool children call for improved ultraviolet protection, but knowledge does not automatically change behavior. ${ }^{65}$ The use of any management decision in children with familial melanoma should be tempered by the findings of a recent study, where atypical nevi in childhood, the nevus count of atypical nevi on the buttocks, and most importantly, the number of excisions during follow-up correlated with the risk of melanoma. ${ }^{66}$ In Caucasian skin, it is believed that the total number of CAMN on the whole body is the most important independent risk factor for melanoma, and the risk of melanoma development increases almost linearly with rising numbers of melanocytic nevi. ${ }^{67}$

The histological morphology of the acquired melanocytic nevi largely dictates the method of removal. The use of lasers is dependent on various factors, including the wavelength and the pulse duration of the laser (Table S1). Thus, in most CAMN, a millisecond pulse duration would be better than the conventional nanosecond lasers (Tables 4 and 5).

It has been the experience of some authors ${ }^{30,60,61}$ that a pulsed ablative laser (ultrapulse $\mathrm{CO}_{2}$ or Er:YAG) can provide an equally effective method of removal of CAMN if a proper dose depth correlation can be ensured. A combination of pigment-specific and ablative lasers can also be used to treat acquired melanocytic nevi (Figure 9).

It has been our experience that subsets of CAMN are hairy and have a propensity for recurrence. This is because the nevus cells tend to extend along hair follicles deeply into skin. The hair follicles therefore harbor nevus cells beyond the depth for effective laser treatment. Techniques of hair removal, whether by laser devices, IPL, or electrolysis may be needed for these lesions.

It must be emphasized that the issue of recurrence and possible dysplasia being missed or melanoma appearing has never been adequately studied, as different techniques have been used in the studies on CAMN. ${ }^{36-40,52-61}$ Needless to say, although most of the excisional techniques ${ }^{36-40}$ may be clinically effective, this cannot absolve the clinician of the consequences of dysplasia or recurrence, as histological confirmation is usually difficult with most excisional techniques. ${ }^{31}$ When using lasers, most clinicians do not biopsy a benign melanocytic nevus or consider a post-treatment biopsy. In such cases, it is advisable to ensure a follow-up and biopsy a recurrent "mole."

Our approach to diagnosis ${ }^{30,31}$ and therapy using lasers $^{47,52-64}$ on CAMN is based on the available evidence and can help in effectively removing most melanocytic nevi (Figure 9). However, as enshrined in the protocol (Figure 9), even after a biopsy, in populations where a risk of melanoma 
is high, the patient should be asked to report back if there is any recurrence, to eliminate the chance of melanoma. Also it should be emphasized that the cosmetic procedure is not a "guarantee" against development of melanoma. There is still inadequate data on recurrence due to the lack of posttreatment biopsy or adequate follow-up. Also, comparative studies using pigment-specific lasers and ablative lasers are lacking, but at present, it can be safely assumed that in most cases, benign melanocytic nevi do not have any significant malignant potential after laser removal.

\section{Disclosure}

The authors report no conflicts of interest in this work.

\section{References}

1. Suh KY, Bolognia JL. Signature nevi. J Am Acad Dermatol. 2009;60: 508-514.

2. Hurwitz RM, Buckel LJ, Eads TJ. Histologic patterns of melanocytic nevi: a proposal for a new classification. J Drugs Dermatol. 2007;6(5):487-492.

3. Ackerman AB, Milde P. Naming acquired melanocytic nevi. Am J Dermatopathol. 1992:14(5):447-453.

4. Barnhill RL, Vernon S, Rabinovitz HS. Benign melanocytic neoplasms. In: Grant-Kels JM, editor. Color Atlas of Dermatopathology. New York: Informa Healthcare USA, Inc; 2007:247-278.

5. MacLennan R, Kelly JW, River JK, Harrison SL. The Eastern Australian Childhood Nevus Study: site differences in density and size of melanocytic nevi in relation to latitude and phenotype. J Am Acad Dermatol. 2003;48:367-375.

6. Wachsmuth RC, Gaut RM, Barrett JH, et al. Heritability and geneenvironment interactions for melanocytic nevus density examined in a UK adolescent twin study. J Invest Dermatol. 200;117:348-352.

7. Oliveria SA, Geller AC, Dusza SW, et al. The Framingham School Nevus Study. Arch Dermatol. 2004;140:545-551.

8. Brogelli L, De Giorgi V, Bini F, Giannotti B. Melanocytic naevi: clinical features and correlation with the phenotype in healthy young males in Italy. Br J Dermatol. 1991;125:349-352.

9. Dellavalle RP, Johnson KR, Hester EJ, et al. Children with red hair have more freckles but fewer melanocytic nevi: results from a cohort study of 280 three-year-olds. Arch Dermatol. 2005;141:1042-1043.

10. Lee TK, Rivers JK, Gallagher RP. Site-specific protective effect of broadspectrum sunscreen on nevus development among white schoolchildren in a randomized trial. J Am Acad Dermatol. 2005;52:786-792.

11. Matichard E, Le Hénanff A, Sanders A, et al. Effect of neonatal phototherapy on melanocytic nevus count in children. Arch Dermatol. 2006;142:1599-1604.

12. Tronnier M, Smolle J, Wolff HH. Ultraviolet irradiation induces acute changes in melanocytic nevi. J Invest Dermatol. 1995;104:475-478.

13. Welch J, Millar D, Goldman A, et al. Lack of genetic and epigenetic changes in CDKN2A in melanocytic nevi. $J$ Invest Dermatol. 2001;117:383-384.

14. Maitra A, Gazdar AF, Moore TO, Moore AY. Loss of heterozygosity analysis of cutaneous melanoma and benign melanocytic nevi: laser capture microdissection demonstrates clonal genetic changes in acquired nevocellular nevi. Hum Pathol. 2002;33:191-197.

15. Cramer SF. The origin of epidermal melanocytes. Arch Pathol Lab Med. 1991;115:115-119.

16. Schmoeckel C. Classification of melanocytic nevi: do nodular and flat nevi develop differently? Am J Dermatopathol. 1997;19:31-34.

17. Tokuda Y, Saida T, Mukai K, Takasaki Y. Growth dynamics of acquired melanocytic nevi. J Am Acad Dermatol. 1994;31:220-224.
18. Worret W-I, Burgdorf WHC. Which direction do nevus cells move? Abtropfung reexamined. Am J Dermatopathol. 1998;20:135-139.

19. Cramer SF. The melanocytic differentiation pathway in Spitz nevi. $A m$ J Dermatopathol. 1998;20:555-570.

20. Zalaudek I, Leinweber B, Hofmann-Wellenhof R, et al. The epidermal and dermal origin of melanocytic tumors: theoretical considerations based on epidemiologic, clinical, and histopathologic findings. Am J Dermatopathol. 2008;30:402-406.

21. MacKie RM, English J, Aitchison TC, et al. The number and distribution of benign pigmented moles (melanocytic naevi) in a healthy British population. Br J Dermatol. 1985;113:167-174.

22. Argenziano G, Zalaudek I, Ferrara G, et al. Proposal of a new classification system for melanocytic naevi. Br J Dermatol. 2007;157: 217-227.

23. Zalaudek I, Grinschgl S, Argenziano G, et al. Age-related prevalence of dermoscopy patterns in acquired melanocytic naevi. Br J Dermatol. 2006;154:299-304.

24. De Giorgi V, Massi D, Salvini C, et al. Dermoscopic features of combined melanocytic nevi. J Cutan Pathol. 2004;31:600-604.

25. Reeck MC, Chuang T-Y, Eads TJ, et al. The diagnostic yield in submitting nevi for histologic examination. J Am Acad Dermatol. 1999;40:567-571.

26. Wu J, Rosenbaum E, Begum S, Westra WH: Distribution of BRAF T1799A(V600E) mutations across various types of benign nevi: implications for melanocytic tumorigenesis. Am J Dermatopathol. 2007;29:534-537.

27. Hashimoto Y, Ito Y, Kato T, et al: Expression profiles of melanogenesisrelated genes and proteins in acquired melanocytic nevus. J Cutan Pathol. 2006;33:207-215.

28. Magana-Garcia M, Ackerman AB. What are nevus cells? Am $J$ Dermatopathol. 1990;12:93-102.

29. Paul E, Cochran AJ, Wen D-R. Immunohistochemical demonstration of S-100 protein and melanoma-associated antigens in melanocytic nevi. J Cutan Pathol. 1988;15:161-165.

30. Sardana K. The science, reality, and ethics of treating common acquired melanocytic nevi (moles) with lasers. J Cutan Aesthet Surg. 2013;6(1):27-29.

31. Culpepper KS, Granter SR, McKee PH. My approach to atypical melanocytic lesions. J Clin Pathol. 2004;57(11):1121-1131.

32. Suzuki H, Anderson RR. Treatment of melanocytic nevi. Dermatol Ther. 2005;18(3):217-226.

33. Drummer R, Kempf W, Burg TG. Pseudomelanoma after laser therapy. Dermatology. 1998;197:71-73.

34. Chan HH. Laser treatment of nevomelanocytic nevi- can results from an Asian study be applicable to the white population? Arch Dermatol. 2002;138:535.

35. Cummins DL, Mimouni D, Anhalt GJ, Nousari CH. Oral cyclophosphamide for treatment of pemphigus vulgaris and foliaceus. J Am Acad Dermatol. 2003;49(2):276-280.

36. Ferrandiz L, Moreno-Ramirez D, Camacho FM. Shave excision of common acquired melanocytic nevi: cosmetic outcome, recurrences, and complications. Dermatol Surg. 2005;31(9 Pt 1):1112-1115.

37. Gambichler T, Senger E, Rapp S, Alamouti D, Altmeyer P, Hoffmann K. Deep shave excision of macular melanocytic nevi with the razor blade biopsy technique. Dermatol Surg. 2000;26(7):662-666.

38. Tursen U, Kaya TI, Ikizoglu G. Round excision of small, benign, papular and dome-shaped melanocytic nevi on the face. Int J Dermatol. 2004;43(11):844-846.

39. Breuninger H, Garbe C, Rassner G. [Shave excision of melanocytic nevi of the skin: indications, technique, results]. Hautarzt. 2000;51(8):575-580. German.

40. Bong JL, Perkins W. Shave excision of benign facial melanocytic naevi: a patient's satisfaction survey. Dermatol Surg. 2003;29(3): 227-229.

41. Cohen LM, Hodge SJ, Owen LG, et al. Atypical melanocytic nevi: clinical and histopathologic predictors of residual tumor at reexcision. J Am Acad Dermatol. 1992;27:701-706. 
42. Barr RJ, Linden KG, Rubinstein G, et al. Analysis of heterogeneity of atypia within melanocytic nevi. Arch Dermatol. 2003;139:289-292.

43. Sommer LL, Barcia SM, Clarke LE, Helm KF. Persistent melanocytic nevi: a review and analysis of 205 cases. J Cutan Pathol. 2011;38(6): 503-507.

44. Chan HHL. Pigmentation and hypopigmentation: benign pigmented lesions. In: Raulin C, Karsai S, editors. Laser and IPL Technology in Dermatology and Aesthetic Medicine. London: Springer Heidelberg Dordrecht; 2011:151.

45. Graber EM, Dover JS. Lasers and lights for treating pigmented lesions. In: Keyvan Nouri, editors. Lasers in Dermatology and Medicine. London: Springer Heidelberg Dordrecht; 2011:72-74.

46. Sardana K, Ranjan R, YadavP, Tenani A. Pigmented lesions and tattoos. In: Sardana K, Garg VK, editors. Lasers in Clinical Practise. Jaypee Publishers, Delhi, India. 2014 [in press].

47. August PJ, Ferguson JE, Madan V. A study of the efficacy of carbon dioxide and pigment-specific lasers in the treatment of mediumsized congenital melanocytic naevi. Br J Dermatol. 2011;164(5): 1037-1042.

48. van Leeuwen RL, Dekker SK, Byers HR, Vermeer BJ, Grevelink JM. Modulation of alpha 4 beta 1 and alpha 5 beta 1 integrin expression: heterogeneous effects of Q-switched ruby, Nd:YAG, and alexandrite lasers on melanoma cells in vitro. Lasers Surg Med. 1996;18: 63-71

49. Chan $\mathrm{HH}$, Xiang $\mathrm{K}$, Leung L, et al. In vitro study examining the effect of sub-lethal QS $755 \mathrm{~nm}$ lasers on the expression of p161nk4a on melanoma cell lines. Lasers Surg Med. 2003;32(2):88-93.

50. Grevelink JM, van Leeuwen RL, Anderson RR, Byers R. Clinical and histological responses of congenital melanocytic nevi after single treatment with Q-switched lasers. Arch Dermatol. 1997;133: 349-353.

51. Goldberg DJ. Benign pigmented lesions of the skin. Treatment with the Q-switched ruby laser. J Dermatol Surg Oncol. 1993;19(4):376-379.

52. Rosenbach A, Williams CM, Alster TS. Comparison of the Q-switched alexandrite $(755 \mathrm{~nm})$ and Q-switched Nd:YAG (1064 nm) lasers in the treatment of benign melanocytic nevi. Dermatol Surg. 1997;23(4):239-244.

53. Vibhagool C, Byers R, Grevelink JM. Treatment of small nevomelanocytic nevi with a Q-switched ruby laser. J Am Acad Dermatol. 1997;36: 738-741.

54. Kim YJ, Whang KU, Choi WB, et al. Efficacy and safety of 1,064 nm Q-switched Nd:YAG laser treatment for removing melanocytic nevi. Ann Dermatol. 2012;24(2):162-167.
55. Duke D, Byers R, Sober AJ, et al. Treatment of benign and atypical nevi with the normal-mode ruby laser and the Q-switched ruby laser: clinical improvement but failure to completely eliminate nevomelanocytes. Arch Dermatol. 1999;135:290-296.

56. Westerhof W, Gamei M. Treatment of acquired junctional melanocytic naevi by Q-switched and normal mode ruby laser. $\mathrm{Br} J$ Dermatol. 2003;148(1):80-85.

57. Wang EC, Sen P, Goh CL, Chua SH. Single treatment with 100microsecond alexandrite laser clears selected acquired melanocytic nevi in type IV Asian facial skin. J Cutan Aesthet Surg. 2013;6(1):21-26.

58. Alshami M. Long-pulsed 532-nm Nd:YAG laser treatment for small acquired melanocytic nevi in a single session: an 8-year study on 350 Yemeni patients. J Cosmet Laser Ther. Epub November 18, 2013.

59. Reda AM, Taha IR, Riad HA. Clinical and histological effect of a single treatment of normal mode alexandrite $(755 \mathrm{~nm})$ laser on small melanocytic nevi. J Cutan Laser Ther. 1999;1(4):209-215.

60. Baba M, Bal N. Efficacy and safety of the short-pulse erbium:YAG laser in the treatment of acquired melanocytic nevi. Dermatol Surg. 2006;32(2):256-260.

61. Hammes S, Raulin C, Karsai S, Bernt R, Ockenfels HM. [Treating papillomatous intradermal nevi: lasers - yes or no? A prospective study]. Hautarzt. 2008;59(2):101-107. German.

62. Ueda S, Imayama A. Normal-mode ruby laser for treating congenital nevi. Arch Dermatol. 1997;133:355-359.

63. Kono T, Erçöçen AR, Chan HH, Kikuchi Y, Nozaki M. Effectiveness of the normal-mode ruby laser and the combined (normal-mode plus Q-switched) ruby laser in the treatment of congenital melanocytic nevi: a comparative study. Ann Plast Surg. 2002:49:476-485.

64. Alster. Cutaneous resurfacing with $\mathrm{CO}_{2}$ and erbium YAG laser. Plast Reconstr Surg. 1999;103:619-632.

65. Wollina U, Helm C, Bennewitz A, Koch R, Schaff K, Burroni M. Interventional Three-year Longitudinal Study of Melanocytic Naevus Development in Pre-school Children in Dresden, Saxony. Acta Derm Venereol. Epub August 8, 2013.

66. Vredenborg A, Böhringer S, Boonk SE, et al. Acquired melanocytic nevi in childhood and familial melanoma. JAMA Dermatol. Epub November 6, 2013.

67. Bauer J, Garbe C. Acquired melanocytic nevi as risk factor for melanoma development. A comprehensive review of epidemiological data. Pigment Cell Res. 2003;16(3):297-306. 


\section{Supplementary material}

Table SI Summary of the use of lasers in common acquired melanocytic nevi

I. Q-switched lasers are inappropriate to treat the nevus clusters as the pulse duration (nanosecond) does not match with the size of the melanocytic nevus, which requires a millisecond laser.

2. The use of lasers is hampered by issues of recurrence, and thus the dose and pulse duration should be "tweaked" depending on the type of common acquired melanocytic nevi.

3. Both pre-laser histological classification of the common acquired melanocytic nevi and post-laser biopsy should be done to assess the depth of tissue damage and to identify the remnant nevus cells which in turn predicts recurrence.

4. Persistence of nevus cells in the deeper layers of the dermis has been observed in all treated nevi except in junctional nevus. Melanin pigmentation tends to decrease in the deep portion of these lesions, for unknown reasons. Treatment with lasers (ruby and alexandrite) that preferentially target the pigmented cells tends to affect only the superficial (approximately $2 \mathrm{~mm}$ deep) portion, because there is more melanin and more laser light impacting near the skin surface.

5. Lighter nevi respond best to shorter wavelengths that maximize melanin absorption, while darker nevi typically respond to any wavelength within the melanin absorption spectrum. It is often unfeasible to attain complete resolution of nevi, and recurrence after laser treatment is common.'

Note: Data from Sardana, ${ }^{2}$ Suzuki and Anderson, ${ }^{3}$ Chan, ${ }^{4}$ Graber and Dover, Sardana et al, ${ }^{6}$ and Westerhof and Gamei. ${ }^{7}$

\section{References}

1. Duke D, Byers R, Sober AJ, et al. Treatment of benign and atypical nevi with the normal-mode ruby laser and the Q-switched ruby laser: clinical improvement but failure to completely eliminate nevomelanocytes. Arch Dermatol. 1999;135:290-296.

2. Sardana K. The science, reality, and ethics of treating common acquired melanocytic nevi (moles) with lasers. J Cutan Aesthet Surg. 2013;6(1):27-29.

3. Suzuki H, Anderson RR. Treatment of melanocytic nevi. Dermatol Ther. 2005;18(3):217-226.

4. Chan HHL. Pigmentation and hypopigmentation: benign pigmented lesions. In: Raulin C, Karsai S, editors. Laser and IPL Technology in Dermatology and Aesthetic Medicine. London: Springer Heidelberg Dordrecht; 2011:151.

5. Graber EM, Dover JS. Lasers and lights for treating pigmented lesions. In: Keyvan Nouri, editors. Lasers in Dermatology and Medicine. London: Springer Heidelberg Dordrecht; 2011:72-74.

6. Sardana K, Ranjan R, YadavP, Tenani A. Pigmented lesions and tattoos. In: Sardana K, Garg VK, editors. Lasers in Clinical Practise. Jaypee Publishers, Delhi, India. 2014 [in press].

7. Westerhof W, Gamei M. Treatment of acquired junctional melanocytic naevi by Q-switched and normal mode ruby laser. $\mathrm{Br} J$ Dermatol. 2003;148(1):80-85.
Clinical, Cosmetic and Investigational Dermatology

\section{Publish your work in this journal}

Clinical, Cosmetic and Investigational Dermatology is an international, peer-reviewed, open access, online journal that focuses on the latest clinical and experimental research in all aspects of skin disease and cosmetic interventions. All areas of dermatology will be covered; contributions will be welcomed from all clinicians and

\section{Dovepress}

basic science researchers globally. This journal is indexed on CAS. The manuscript management system is completely online and includes a very quick and fair peer-review system, which is all easy to use. Visit http://www.dovepress.com/testimonials.php to read real quotes from published authors. 